\title{
JUURNAL.RU
}

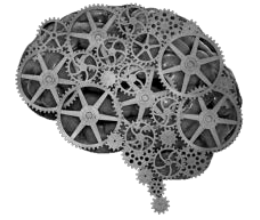

COMPANY GROUP "INTELLEKT"

\author{
Петунин О.В. \\ Кузбасский региональный институт повышения квалификащии и переподготовки \\ работников образования \\ Кемерово, Россия
}

doi: 10.18411/lj2016-8-1-11

idsp 000001:lj2016-17-1-11

\section{О процессуальной стороне образовательной деятельности в свете требований ФГОС общего образования}

«Время есть величайший из новаторов», - говорил английский философ Френсис Бэкон [1]. Время затрагивает все сферы человеческой жизни, в том числе и образование, периодически требуя его обновления. Как показала массовая практика, задача формирования новой личности неосуществима традиционными подходами к образованию. Поэтому введение новых образовательных стандартов - это веяние времени.

Понятие стандарта происходит от английского слова standart, означающего «норма, образец, мерило». Под стандартом образования понимается система основных параметров, принимаемых в качестве государственной нормы образованности, отражающей общественный идеал и учитывающей возможности реальной личности и системы образования по достижению этого идеала.

Что такое государственный стандарт, знали еще в советское время, поскольку жесткий регламент существовал на всех этапах развития образования нашей страны. Но конкретный документ под названием «государственный образовательный стандарт» (ГОС) общего образования появился и вступил в силу лишь в 2004 г. Нынешние стандарты получили название Федеральных государственных образовательных стандартов (ФГОС).

Определяющим фактором возникновения стандартизации в России выступает стремление к повышению качества образования. Стандарты всех уровней образования призваны обеспечить общекультурные, общечеловеческие, 
общегосударственные требования к образованию на основе самоопределения и саморазвития личности. Отметим еще раз, что главная функция стандарта повышение качества образования.

Качество образования - многокомпонентное явление, включающее не только качество учебного процесса и педагогической деятельности или научнопедагогических кадров и образовательных программ, но и качество (уровень) материально-технической базы и информационно-образовательной среды, а также качество управления и исследований. Эти и ряд других требований к организации образовательного процесса в широком смысле этого слова прописаны в ФГОС [3; 4].

В Кемеровской области накоплен актуальный опыт внедрения ФГОС. Так, ФГОС начального общего образования в регионе внедряется с 2010 г., ФГОС основного общего образования с 2012 г. (в 2016/2017 учебном году в 6-ти образовательных организациях по ФГОС ООО будут обучаться учащиеся 9-х классов), а ФГОС среднего общего образования с 2014 г. (в 2016/2017 учебном году в 10-ти образовательных организациях будет осуществляться пилотная апробация ФГОС СОО). Это позволяет нам, с одной стороны, - выявить основные трудности, испытываемые педагогами при реализации требований ФГОС, а с другой - указать адреса лучших педагогических практик и широко транслировать их в регионе.

Как показывает практика, для того чтобы внедрение ФГОС привело к повышению качества образования, необходимо изменить согласно требованиям стандарта все компоненты образовательного процесса: его цели, содержание, технологии, методы и приемы обучения и воспитания, а также подходы к оценке образовательных достижений учащихся.

Остановимся подробней на процессуальной стороне образовательной деятельности, к изменениям дидактического характера на учебном занятии согласно ФГОС.

Российское образование, к сожаленью, в массе по-прежнему остаётся репродуктивным - и в детском саду и в школе. Несмотря на многочисленные попытки педагогов изменить подходы к обучению и воспитанию, внедрить инновационные личностно развивающие модели, мы по-прежнему чаще всего сталкиваемся с репродуктивными технологиями обучения и воспитания. 
Надо отдать должное начальной школе. Здесь часто решаются задачи, соответствующие мировым тенденция развития образования. Но что касается основной ступени общего образования - подростковой школы, то, как правило, на этой ступени реализуется традиционная знаниевая модель. В старших классах идёт профилизация. Между тем в старшей школе нередко образовательные технологии также остаются в рамках традиционной модели. Даже система дополнительного образования грешит этим.

Решению задачи по переходу от информационно-трансляторской к деятельностной модели образования во многом способствует реализация в образовательном процессе системно-деятельностного подхода - основы ФГОС.

Понятие «подход» с момента своего появления в науке означает особый угол зрения на объект исследовательской деятельности. Категория «системнодеятельностный подход» была впервые введена в научный обиход в 1985 году. До этого времени в психолого-педагогической науке разрабатывались два понятия:

- системный подход (Б. Г. Ананьев, Б. Ф. Ломов и др.), который предполагает осуществление системного анализа: определение состава объекта исследования, его функций, описание существенных признаков, отношений, связей между ними, что исключает их трактовку как автономных образований;

- деятельностный подход (Л. С. Выготский, В. В. Давыдов, Л. В. Занков и др.), согласно которому развитие личности, формирование тех или иных ее качеств возможно только в деятельности [2].

Таким образом, введение понятия «системно-деятельностный подход» послужило попыткой объединения системного и деятельностного подходов в единую научную категорию.

Очевидно, что реализация в образовательной деятельности системнодеятельностного подхода, как одной из главных особенности ФГОС, не может быть не учтена педагогом при проектировании учебного занятия.

Согласно системно-деятельностному подходу, сегодня на занятии учащийся должен принимать участие: 
- в целеполагании и постановке задач занятия на основе сопоставления своих знаний и выявленных познавательных затруднений;

- проектировании пошаговой деятельности на пути к результату, то есть к поставленной цели занятия;

- проведении проверки и оценки полученных результатов деятельности (самоконтроль, самооценка и взаимный контроль, взаимное оценивание);

- корректировании учебной деятельности в случае наличия познавательных затруднений;

- рефлексии деятельности по итогам занятия;

- выборе дифференцированного домашнего задания с учётом собственных возможностей и уровня притязаний [2].

Суть изменений, связанных с проведением учебного занятия «деятельностного» типа отражает таблица 1.

Таблициа 1

Различия в требованиях к традиичонному и «деятельностному» учебным занятиям

\begin{tabular}{|c|c|c|}
\hline $\begin{array}{c}\text { Требования к учебному } \\
\text { занятию }\end{array}$ & Традиционное учебное занятие & «Деятельностное» учебное занятие \\
\hline Тема & $\begin{array}{c}\text { Формулируется и объявляется } \\
\text { педагогом }\end{array}$ & Формулируется учащимися \\
\hline Цель и задачи & $\begin{array}{c}\text { Проектируются и предъявляются } \\
\text { классу педагогом }\end{array}$ & Определяются учащимися \\
\hline $\begin{array}{l}\text { Планирование } \\
\text { деятельности }\end{array}$ & Планируется педагогом & $\begin{array}{c}\text { Учащимися самостоятельно } \\
\text { планируют способы достижения } \\
\text { поставленной цели занятия }\end{array}$ \\
\hline $\begin{array}{c}\text { Практическая деятельность } \\
\text { учащихся }\end{array}$ & $\begin{array}{c}\text { Осуществляется под } \\
\text { непосредственным руководством } \\
\text { педагога } \\
\end{array}$ & $\begin{array}{c}\text { Учащиеся работают самостоятельно } \\
\text { по намеченному заранее плану }\end{array}$ \\
\hline Контроль & Осуществляется педагогом & $\begin{array}{l}\text { Самоконтроль и взаимоконтроль, } \\
\text { учитель играет роль консультанта }\end{array}$ \\
\hline $\begin{array}{c}\text { Корректировочная } \\
\text { деятельность }\end{array}$ & Проводится педагогом & $\begin{array}{c}\text { Школьники на основе выявленных } \\
\text { интеллектуальных затруднений } \\
\text { проводят самостоятельно }\end{array}$ \\
\hline Оценивание учащихся & Осуществляется педагогом & Самооценка, взаимное оценивание \\
\hline Итоги занятия & Подводятся педагогом & Проводится рефлексия \\
\hline Домашнее задание & $\begin{array}{c}\text { Задается и комментируется } \\
\text { педагогом }\end{array}$ & $\begin{array}{c}\text { Школьники выбирают задание из } \\
\text { предложенных вариантов }\end{array}$ \\
\hline
\end{tabular}

Очевидно, что обучение невозможно при полном исключении из дидактического арсенала педагога роли транслятора знаний, репродуктивных методов обучения. Как показывает практический опыт, для того, чтобы процессуальный компонент образовательного процесса способствовал 
повышению его качества, необходимо добиваться их гармоничного сочетания. Рецепт данного гармоничного синтеза сложен и индивидуален на каждом учебном занятии. Он определяется степенью мотивированности класса (группы) к изучению данного предмета, степенью подготовленности класса (группы), уровнем сложности и объемом изучаемого материала, возрастом детей и т. д.

Таким образом, опыт лучших образовательных организаций и педагогов показывает, что целенаправленная и педагогически грамотная реализация требований ФГОС к процессуальной стороне образовательной деятельности может привести к существенному повышению ее качества.

\section{Литература:}

1. Бэкон, Ф. Афоризмы и цитаты [Электронный ресурс] / Ф. Бэкон. - Режим доступа: http://citaty.su/aforizmy-i-citaty-frensisa-bekona (свободный).

2. Петунин, О. В. Познавательная самостоятельность учащейся молодежи [Текст]: монография /О. В. Петунин. - Томск: Изд-во Томского университета, 2010. - $372 \mathrm{c}$.

3. Федеральный государственный образовательный стандарт основного общего образования [Электронный ресурс]. - Режим доступа: http://standart.edu.ru/catalog.aspx?CatalogId=2588 (свободный).

4. Федеральный государственный образовательный стандарт среднего (полного) общего образования. - Режим доступа: http://standart.edu.ru/catalog.aspx?CatalogId=6408 (свободный). 